\title{
Peraturan Presiden Nomor 58 Tahun 2014 tentang Rencana Tata Ruang Wilayah Kawasan Strategis Nasional Borobudur dan Sekitarnya sebagai Payung Hukum Konservasi Kawasan Cagar Budaya Borobudur
}

\author{
Sri Sularsih \\ Balai Konservasi Borobudur \\ Email: nuraini1987@ymail.com
}

\begin{abstract}
Abstrak: Pemanfaatan ruang di Kawasan Borobudur membutuhkan perhatian lebih oleh Pemerintah maupun Pemerintah Daerah. Maraknya pembangunan tak berizin di sekitar kawasan terutama sepanjang Koridor Palbapang yang semakin lama semakin tidak terkendali, jika tidak dilakukan pemantauan dan evaluasi serta tindak lanjut maka akan semakin menjauhkan angan dalam rangka mewujudkan suatu kawasan cagar budaya yang lestari dan berkelanjutan. Masih lemahnya penegakan peraturan dan minimnya pemahaman masyarakat terkait Kawasan Borobudur menjadi faktor semakin meningkatnya pemanfaatan lahan yang perlu segera untuk dilakukan pengendalian. Diterbitkannya Peraturan Presiden Nomor 58 Tahun 2014 tentang Rencana Tata Ruang dan Wilayah Kawasan Strategis Nasional Borobudur dan Sekitarnya menjadi langkah nyata dalam pengendalian pemanfaatan ruang di Kawasan Borobudur. Kondisi pemanfaatan ruang yang ada saat ini perlu dikaji lebih lanjut dengan penegakan aturan yang semestinya.
\end{abstract}

Kata kunci : Kawasan Borobudur, pemanfaatan ruang, penegakan peraturan

Abstract: The spatial usage in Borobudur area needs serious attention from central and local government. Unauthorized buildings are getting erected in the area, especially in the Palbapang Corridor, which is affected by weak control. Continuous monitoring and evaluation, as well as strict follow up, should be conducted to reach the dream of sustainable cultural heritage area. Weak enforcement and lack of understanding from the community regarding the Borobudur area have affected the rise of uncontrolled spatial usage. The issuance of Presidential Regulation Number 58 Year 2014 regarding Spatial and Area Planning of Borobudur and its Surrounding Area is a tangible proof in the strong desire to manage the spatial usage in Borobudur area. The present condition of spatial usage should be studied further in enforcing related regulations.

Keywords: Borobudur area, spatial usage, regulation enforcement

\section{Pendahuluan}

Telah banyak tulisan yang membahas mengenai Candi Borobudur dan Kawasannya serta permasalahan yang terjadi baik dalam rangka pengelolaan maupun eksistensinya sampai saat ini. Kawasan Borobudur merupakan KawasanStrategisNasional yang ditetapkan .oleh Kementerian Pekerjaan Umum pada tahun 2014. Oleh sebab itu masih banyak hal yang menjadi perhatian demi mewujudkan Kawasan Borobudur sebagai KawasanStrategisNasional di bidang kebudayaan, yang mampu menjadi leading sector dari pengelolaan dan pelestarian kawasan cagar budaya lainnya.

Kawasan Strategis Nasional (yang selanjutnya disingkat KSN) adalah wilayah yang penataan ruangnya diprioritaskan karena mempunyai pengaruh sangat penting secara nasional terhadap kedaulatan negara, pertahanan dan keamanan negara, ekonomi, sosial, budaya, dan/atau lingkungan, termasuk wilayah yang telah ditetapkan sebagai warisan dunia. Di Indonesia, warisan dunia terdiri dari warisan dunia alam dan warisan dunia budaya (cagar budaya). Warisan dunia alam meliputi Taman Nasional Ujung Kulon di Banten, Taman Nasional Komodo di Nusa Tenggara Timur, Taman Nasional Lorentz di Papua, dan Warisan Hutan Hujan Tropis Sumatera di Sumatera, yang terdiri dari Taman Nasional Gunung Leuser; Taman Nasional Kerinci Seblat; dan Taman Nasional Bukit Barisan Selatan. Warisan dunia budaya meliputi tangible dan intangible. Warisan budaya dunia yang bersifat kebendaan (tangible) yaitu Kompleks Candi Borobudur, Kompleks Candi Prambanan, Situs Prasejarah Sangiran, dan Lanskap Budaya Provinsi Bali: Sistem Subak sebagai Perwujudan dari Filosofi Tri Hita Karana, sedangkan warisan budaya dunia tak benda (intangible) terdiri dari Wayang, Keris, Batik, Angklung, Tari Saman, dan Noken.

Warisan dunia yang saat ini telah ditetapkan pula sebagai KSN oleh Kementerian Pekerjaan Umum antara lain Kawasan Borobudur, sedangkan Kawasan 
Prambanan, Kawasan Sangiran, dan Kawasan Subak Bali masih dalam proses penetapan.Pada kenyataannya, penetapan kawasan - kawasan tersebut tidaklah secara berurutan. Dapat dilihat misalnya pada Kawasan Borobudur yang ditetapkan terlebih dahulu sebagai warisan dunia, kemudian penetapannya sebagai KSN, dan terakhir tahun 2014 yang lalu ditetapkan sebagai Kawasan Cagar Budaya peringkat nasional melalui keputusan menteri. Memang seharusnya penetapan tersebut dilakukan sebaliknya, namun mengingat urgensinya, Kawasan Borobudur saat itu ditetapkan sebagai warisan dunia oleh UNESCO terlebih dahulu.

Kawasan Borobudur sangat perlu dijaga keserasian dan kelestarian lansekap saujananya terutama di sepanjang Koridor Palbapang. Kondisi yang ada saat ini, bahkan semakin meningkat dari waktu ke waktu adalah pemanfaatan ruang terbuka terutama lahan hijau untuk pembangunan rumah tinggal baik yang berizin maupun yang tidak berizin (hasil monitoring okawasan 2015). Yang perlu diwaspadai dan dilakukan monitoring secara berkala adalah adanya pendirian bangunan baru yang dapat mengganggu visualisasi lansekap Kawasan Borobudur terlebih jika pendirian bangunan tersebut tidak memiliki izin yang resmi. Secara garis besar, permasalahan terkait pemanfaatan ruang di Kawasan Borobudur adalah sebagai berikut :

a. Permasalahan apa saja yang dihadapi dalam rangka implementasi Peraturan Presiden Nomor 58 Tahun 2014 tentang Rencana Tata Ruang dan Wilayah Kawasan Strategis Nasional Borobudur dan Sekitarnya untuk mewujudkan pelestarian Kawasan Borobudur?

b. Bagaimana tindak lanjut untuk menangani permasalahan yang dihadapi dalam pelestarian Kawasan Borobudur tersebut?

\section{Hasil dan Pembahasan}

\section{A. Data Monitoring Kawasan Borobudur}

Monitoring Kawasan Borobudur dilaksanakan secara berkala sejak tahun 2011 oleh tim monitoring Balai Konservasi Borobudur. Dalam pelaksanaan monitoring kawasan tersebut, tim monitoring melakukan pendataan terkait dengan perubahan demografi kependudukan, perubahan infrastruktur bangunan, perubahan tata guna lahan, dan potensi temuan cagar budaya. Data yang diperoleh dari tahun ke tahun terkait dengan perubahan tata guna lahan maupun infrastruktur bangunan adalah mengalami kenaikan. Hal ini menunjukkan bahwa kegiatan pemanfaatan ruang di Kawasan Borobudur sangat menarik signifikan.

Dari kegiatan monitoring kawasan ini pula, diketahui bahwa di masyarakat pun status Kawasan Borobudur ini sangat menjadi polemik yang menimbulkan pro dan kontra. Pada satu sisi, masyarakat berharap tingkat kehidupan yang lebih baik dan pada saat yang bersamaan, investor memberikan penawaran yang memang dibutuhkan masyarakat terkait jual beli lahan milik masyarakat walaupun pada kenyataannya hal tersebut masih terhambat dengan perizinan pemanfaatan ruang. Dari hasil monitoring di lapangan, dapat diketahui tingkat perubahan pemanfaatan ruang di kawasan dalam beberapa tahun terakhir.

Pada peta Perubahan Penggunaan Lahan Subkawasan Pelestarian I Kawasan Borobudur, dapat dilihat bahwa dari tahun 2005 sampai dengan tahun 2013 terdapat perubahan penggunaan lahan yang signifikan tersebar di Kawasan Borobudur terutama di SP I termasuk di area Koridor Palbapang (warna hijau). Perubahan lahan yang terjadi diantaranya pembangunan rumah tinggal, perluasan bangunan baik rumah maupun gedung, dan perluasan industri maupun perdagangan jasa. Pembangunan tersebut banyak yang belum memiliki Ijin Mendirikan Bangunan (IMB) karena pihak dinas terkait (BPMPPT KabupatenMagelang) yang masih belum bisa menerbitkan ijin pendirian bangunan dikarenakan masih adanya moratorium terkait saat itu belum terbitnya Perpres KSN. Moratorium dilaksanakan sejak tahun 2008 sehingga bangunan terbangun dari tahun 2008 sampai dengan 2013 sebagian besar tidak berijin (FGD pada tanggal 28 Agustus 2015). Alhasil yang ditemui di lapangan adalah terbangunnya lahan yang semula adalah lahan basah maupun lahan kering tanpa ijin pendiriannya. Untuk besaran luas perubahan yang terjadi dapat dilihat pada tabel Interpretasi luasan penggunaan lahan berdasarkan citra satelit 2013 disamping.

Pada Tabel Interpretasi luasan penggunaan laban berdasarkan citra satelit 2013, angka yang berwarna kuning dapat dilihat bahwa terjadi perubahan berupa penambahan luas bangunan yang dalam hal ini menunjukkan pertumbuhan lahan terbangun selama 5 


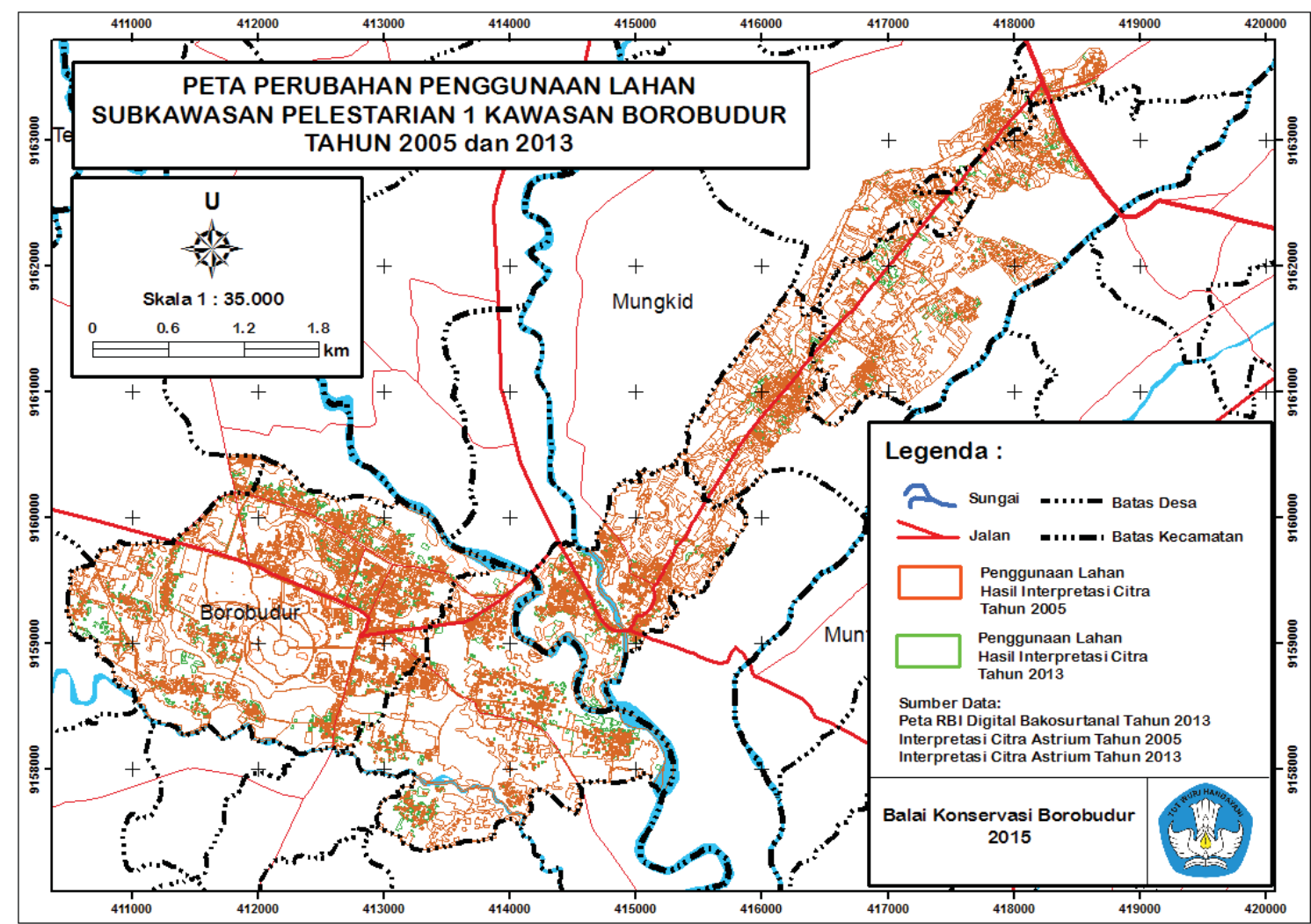

Peta Perubahan Penggunaan Lahan Subkawasan Pelestarian I Kawasan Borobudur Sumber : Dokumentasi BKB 2015

Tabel Interpretasi luasan penggunaan lahan berdasarkan citra satelit 2013

\begin{tabular}{clrrr} 
No & \multicolumn{1}{c}{ Obyek } & Luas tahun 2005 & Luas tahun 2013 & Perubahan \\
\hline 1 & Gedung & 2,114462 & 2,913519 & 0,799057 \\
2 & Gereja & 0,274092 & 0,369052 & 0,09496 \\
\hline 3 & Hotel & 1,891808 & 2,773952 & 0,882144 \\
4 & Industri & 0,550038 & 0,68048 & 0,130442 \\
\hline 5 & Jalan & 35,871295 & 35,869549 & $-0,001746$ \\
\hline 6 & Kantor & 2,320912 & 2,601347 & 0,280435 \\
\hline 7 & Kebun campur & 489,59486 & 443,1746 & $-46,42026$ \\
\hline 8 & Kolam & 34,545724 & 32,745075 & $-1,800649$ \\
\hline 9 & Lahan terbuka & 92,866193 & 107,382189 & 14,515996 \\
\hline 10 & Lapangan & 6,992636 & 6,361206 & $-0,63143$ \\
\hline 11 & Layanan kesehatan & 0,198138 & 0,418857 & 0,220719 \\
12 & Masjid & 1,1097 & 1,37646 & 0,26676 \\
\hline 13 & Pekarangan & 44,22329 & 72,171663 & 27,948373 \\
\hline 14 & Perdagangan jasa & 11,723896 & 14,813508 & 3,089612 \\
\hline 15 & Rumah & 76,024073 & 87,489439 & 11,465366 \\
\hline 16 & Sawah & 246,161745 & 251,789404 & 5,627659 \\
\hline 17 & Sekolah & 3,061331 & 4,853317 & 1,791986 \\
\hline 18 & Taman rekreasi & 1,456047 & 1,437855 & $-0,018192$ \\
\hline 19 & Tegalan & 259,721529 & 239,962149 & $-19,75938$ \\
\hline 20 & Tempat parkir & 2,555187 & 3,891219 & 1,336032 \\
\hline 21 & Vihara & 0,236485 & 0,535752 & 0,299267 \\
\hline
\end{tabular}

Sumber : Dokumen BKB 2015 
(lima) tahun, sedangkan pada tabel angka berwarna ungu terjadi perubahan berupa pengurangan luas lahan jalan, kebun campur, kolam, lapangan, tegalan, dan taman rekreasi yang dimungkinkan dikarenakan penyempitan lahan untuk pembangunan bangunan baru maupun untuk lahan hijau. Yang menjadi perhatian juga adalah tabel angka yang berwarna hijau yang seharusnya angka luasan berkurang seiring perkembangan pembangunan yang terjadi tetapi sebaliknya mengalami penambahan luas lahan terbuka, pekarangan, dan sawah. Hal ini dimungkinkan dikarenakan memang terjadi penambahan lahan di beberapa area namun juga dapat dimungkinkan bahwa saat pengukuran citra satelit pada tahun 2005 dan tahun 2013 dilaksanakan tidak dalam bulan yang sama. Misalnya pada tahun 2005 dilaksanakan pada musim kemarau sehingga lahan hijau yang nampak tidak seperti pada tahun 2013 yang diukur citra satelit pada musim penghujan. Pada dasarnya, tabel interpretasi luasan penggunaan lahan di atas menunjukkan bahwa perubahan penggunaan lahan terutama pengurangan lahan hijau semakin meningkat dari tahun ke tahun (table warn kuning).

Dari hasil monitoring di lapangan, berdasarkan wawancara dengan beberapa aparat di Desa Ngrajek diketahui pula bahwa di desa tersebut pernah terdapat pengajuan ijin pendirian bangunan untuk rumah tinggal, namun pada kenyataannya rumah tinggal yang dimaksud adalah dalam bentuk penginapan, bukan rumah tinggal keluarga. Berikut ini salah satu bangunan yang awal pengajuan pendirian di tingkat desa berupa rumah tinggal.

\section{B. Permasalahan yang Dihadapi dalam Pelestarian Kawasan dalam Rangka Implementasi Peraturan Presiden Nomor 58 Tahun 2014 tentang Rencana Tata Ruang dan Wilayah Kawasan Strategis Nasional Borobudur dan Sekitarnya}

Fenomena di masyarakat yang saat ini sedang menjadi topik hangat adalah ditetapkannya Kawasan Borobudur sebagai Kawasan Strategis Nasional (KSN) di bidang kebudayaan oleh Kementerian Pekerjaan Umum yang merupakan tindak lanjut dari Undang - undang Nomor 26 Tahun 2007 tentang Penataan Ruang dan Peraturan Pemerintah Nomor 26 Tahun 2008 tentang Rencana Tata Ruang Wilayah Nasional (RTRWN) dimana dinyatakan bahwa yang termasuk dalam KSN adalah salah satunya warisan budaya dunia.Penetapan wilayah tersebut secara otomatis berdampak terhadap pengendalian pemanfaatan ruang di Kawasan Borobudur yang merupakan salah satu kawasan strategis nasional.

Candi Borobudur, Candi Mendut, dan Candi Pawon beserta lingkungannya ditetapkan oleh UNESCO sebagai World Heritage atau yang lebih dikenal dengan sebutan Kompleks Candi Borobudur. Kompleks Candi Borobudur termasuk area sepanjang koridor Palbapang, pada tahun 2014 yang lalu ditetapkan pula sebagai KSN. Disusul dengan penetapannya sebagai Kawasan Cagar Budaya peringkat nasional. Penetapan Kawasan Borobudur sebagai KSN ditetapkan melalui Peraturan Presiden Nomor 58 Tahun 2014 tentang Rencana Tata Ruang dan Wilayah Kawasan Strategis Nasional Borobudur dan Sekitarnya, sedangkan penetapan sebagai Kawasan Cagar Budaya ditetapkan melalui Keputusan Menteri Pendidikan dan Kebudayaan Republik Indonesia Nomor 286/M/2014 tentang Satuan Ruang Geografis Borobudur sebagai Kawasan Cagar Budaya Peringkat Nasional.

Sesuai peraturan perundang-undangan tersebut, Kompleks Candi Borobudur untuk selanjutnya disebut sebagai Kawasan Borobudur adalah Kawasan Strategis Nasional yang mempunyai pengaruh sangat pentingterhadap budaya yang berada dalam radius paling sedikit 5 (lima) kilometer dari pusat Candi Borobudur, yang terdiri atas Subkawasan Pelestarian I (SP 1) dan Subkawasan Pelestarian II (SP 2) serta telah ditetapkan sebagai Warisan Budaya Dunia dalam dokumen Daftar Warisan Dunia Nomor C-592. Oleh sebab itu, pengaturan pengendalian dan pemanfaatan ruang di kawasan ini tidak hanya dilaksanakan oleh salah satu pihak saja, melainkan saling terkait antar para pemangku kepentingan (stakeholder) baik pemerintah pusat, pemerintah daerah, maupun masyarakat.

Polemik yang muncul di kalangan masyarakat adalah mayoritas mengenai masalah pemanfaatan lahan yang mereka miliki. Setelah adanya penetapan Kawasan Borobudur sebagai KSN ini, masyarakat merasa bahwa hak kepemilikan mereka dibatasi. Jika dilihat dari substansi perpres mengenai KSN, terdapat beberapa point permasalahan ataupunkendalayang seringkali dijumpai di 
masyarakat terkaitimplementasiPerpres KSN diantaranya yaitu (Hasil monitoring dan evaluasi kawasan 2015) :

1. Masyarakat merasa hak kepemilikan lahan miliknya dibatasi

Terutama pada masyarakat yang berada dalam jalur Koridor Palbapang yang sebagian lahan miliknya merupakan lahan hijau kawasan dikarenakan masih berupa persawahan. Konflik yang terjadi adalah jika masyarakat ingin menjual lahan miliknya dikarenakan kebutuhan ekonomi yang mendesak namun harga yang didapat adalah lebih rendah dibandingkan dengan sebelum adanya penetapan wilayah KSN (berdasarkan wawancara dengan masyarakat). Hal itu juga mengalami kendala terkait dengan pihak pembeli yang memang akan berfikir 2 kali ketika akan membeli lahan di Kawasan Borobudur dikarenakan adanya pembatasan pembangunan fisik di kawasan. Masyarakat yang ingin melakukan pembangunan lahan atau alih fungsi lahan miliknya sendiri seringkali tidak mengajukan perizinan kepada pemerintah daerah karena merasa takut tidak akan mendapat izin pendirian bangunan terutama untuk usaha komersil.

2. Pihak investor yang "menabung" lahan di Kawasan Borobudur

Permasalahan yang sangat urgent di masyarakat adalah sebagian besar lahan sawah maupun tegalan milik masyarakat saat ini dimiliki oleh pihak luar atau swasta. Misalnya saja beberapa lahan di Desa Pabelan dimilik oleh seorang pengusaha besar di Magelang dan oleh perusahaan rokok terkenal di Indonesia. Begitupun dengan lahan masyarakat di desa-desa yang termasuk dalam Kawasan Borobudur. Hal tersebut dapat terjadi karena masih kurangnya pemahaman masyarakat dan keadaan perekonomian masyarakat yang mendorongnya untuk menjual lahan yang dimiliki karena memang masyarakat masih beranggapan bahwa dengan adanya KSN ini, peruntukkan dan perubahan fungsi ruang yang ada dibatasi oleh aturan pemerintah. Memang sangat diperlukan peningkatan pemahaman masyarakat bahwa KSN ini akan bermanfaat tidak secara instans, melainkan membutuhkan waktu dan peran serta stakeholder termasuk masyarakat itu sendiri. Selain itu, kaitannya dengan jual beli lahan yang berada di area kawasan, hal tersebut didukung dengan adanya "makelar tanah" yang merupakan warga dari dusun atau desa dimana tanah tersebut berada dengan "iming-iming" berupa dukungan finansial.

3. Belum maksimalnya sosialisasi kepada masyarakat terkait dengan penetapan KSN

Sosialisasi dilaksanakan oleh Kementerian Pekerjaan Umum dan Perumahan Rakyat baik tingkat daerah maupun pusat kepada masyarakat di KSN Borobudur, hanya saja target sosialisasi yang dilaksanakan beberapa kali dihadiri oleh aparat desa dan tidak menyentuh masyarakat secara langsung. Masyarakat yang berada dalam wilayah Kawasan Borobudur adalah masyarakat yang sangat membutuhkan informasi terkait dengan penetapan Kompleks Candi Borobudur sebagai KSN dan mengenai aturan-aturan pemanfaatan ruang yang ada. Alangkah baiknya jika sosialisasi dari Kementerian Pekerjaan Umum dan Perumahan Rakyat ditargetkan langsung kepada masyarakat di masing-masing desa bahkan dusun yang termasuk dalam Kawasan Borobudur. Selain sebagai sarana pemahaman kepada masyarakat, juga bisa didapat aspirasi dari masyarakat terkait permasalahan maupun peran serta masyarakat dalam pelestarian kawasan.

4. Belum sinerginya program kerja antar instansi terkait Program kerja jangka 2015 - 2019 dalam rangka penataan ruang Kawasan Borobudur sangat membutuhkan peran serta para pemangku kepentingan baik Kementerian Pekerjaan Umum dan Perumahan Rakyat, Kementerian Pendidikan dan Kebudayaan, Kementerian Pertanian, Kementerian Agraria dan Tata Ruang, Kementerian Pariwisata, Kementerian Dalam Negeri, Pemerintah Daerah Kabupaten Magelang diantaranya adalah Dinas Pariwisata dan Kebudayaan, Bappeda, BPMPPT, Dinas PU dan ESDM dan kementerian maupun dinas terkait lainnya. Alangkah baiknya jika pada awal program kerja tahunan, dilaksanakan kegiatan rapat koordinasi antar lintas sektoral berkepentingan guna mengsinergikan program kerja 
masing-masing instansi yang memiliki wewenang terhadap Kawasan Borobudur.

5. Belum maksimalnya penegakan aturan oleh pemerintah dan/atau pemerintah daerah

Walaupun telah ada moratorium terkait dengan pembangunan lahan di area Kawasan Borobudur terutama di sepanjang Koridor Palbapang namun tetapsaja marak pembangunan lahan yang terjadi dan hal ini semakin meningkat dikarenakan belum adanya tindakan yang pasti dari instansi yang berwenang terkait dengan penegakan aturan perizinan pendirian bangunan.

\section{Penanganan Permasalahan dalam Implementasi Peraturan Presiden Nomor 58 Tahun 2014 tentang Rencana Tata Ruang Kawasan Borobudur dan Sekitarnya}

Seperti yang tercantum dalam Pasal 2 Peraturan Presiden Nomor 58 Tahun 2014 tentang Rencana Tata Ruang Kawasan Borobudur dan Sekitarnya (selanjutnya disebut Perpres Kawasan Borobudur) bahwa lingkup pengaturan dari peraturan presiden tersebut adalah sebagai berikut:

- Peran dan fungsi rencana tata ruang serta cakupan Kawasan Borobudur

- Tujuan, kebijakan, dan strategi penataan ruang Kawasan Borobudur

- Rencana struktur ruang Kawasan Borobudur

- Rencana pola ruang Kawasan Borobudur

- Arahan pemanfaatan ruang Kawasan Borobudur

- Arahan pengendalian pemanfaatan ruang Kawasan Borobudur

- Pengelolaan Kawasan Borobudur

- Peran masyarakat dalam penataan ruang Kawasan Borobudur

Dari point-point yang tersebut di atas, subtansi yang diatur dalam hal ini adalah bagaimana pengelolaan Kawasan Borobudur sebagai Kawasan Strategis Nasional, Kawasan Cagar Budaya Peringkat Nasional, dan Warisan Budaya Dunia melalui penyelenggaran penataan ruang. Di lampiran Perpres Kawasan Borobudur tersebut, telah diatur mengenai aturan-aturan pemanfaatan lahan untuk bangunan pemukiman, komersial, maupun fasilitas umum yang dilaksanakan di tiap-tiap dusun yang termasuk dalam SP I Kawasan Borobudur. Langkah-langkah yang dapat diambil oleh stakeholder di Kawasan Borobudur adalah sebagai berikut :

1. Mereview Peraturan Daerah Kabupaten Magelang Nomor 5 Tahun 2011 tentang Rencana Tata Ruang Wilayah Kabupaten Magelang Tahun 2010 - 2030 Dari hasil Focus Grup Discusion (FGD) yang dilaksanakan di Bappeda Kabupaten Magelang pada tanggal 28 Agustus 2015 diketahui bahwa terdapat beberapaketidaksesuaian antara data di lapangan dengan lampiran peta pada Perpres Kawasan Borobudur diantaranya adalah wilayah dusun yang seharusnya termasuk dalam Desa Wringinputih, dalam lampiran peta termasuk dalam Desa Borobudur dimana hal tersebut memiliki dampak signifikan terhadap pengaturan perubahan tata guna lahannya karena Desa Wringinputih termasuk dalam SP II, sedangkan Desa Borobudur termasuk dalam SP I yang mana perubahan tata guna lahannya terbatas. Dalam hal ini, perlu segera dilaksanakan klarifikasi dan revisi terhadap perda penataan ruang di Kabupaten Magelang.

2. Melakukan sosialisasi Peraturan Presiden Nomor 58 Tahun 2014 tentang Rencana Tata Ruang Kawasan Borobudur dan Sekitarnya

Masyarakat yang berada di Kawasan Borobudur masih belum sepenuhnya memahami mengenai konsep pengelolaan Kawasan Cagar Budaya dalam kaitannya sebagai Kawasan Strategis Nasional. Diperlukan adanya sosialisasi kepada masyarakat agar informasi yang disampaikan tidak menimbulkan kesimpangsiuran.

3. Melakukan penataan dan penertiban terhadap sarana informasi di sepanjang area Koridor Palbapang

Pasal 30 ayat (2) menyatakan bahwa peraturan zonasi disusun salah satunya dengan memperhatikan pengendalian bentang pandang. Pengendalian bentang pandang yang dimaksud adalah untuk mengendalikan arah pandang dari kawasan situs candi termasuk taman candi ke arah Gunung Sindoro, Gunung Telomoyo, Gunung Andong, Gunung Ayamayam, Gunung Tidar, dan Gunung Sumbing, serta arah pandang di sepanjang Jalan Strategis Nasional. Pengendalian 
arah pandang di sepanjang Jalan Strategis Nasional ini lebih terkonsentrasi pada sepanjang koridor Palbapang, dengan maraknya bangunan maupun papan reklame yang dipasang dapat mengganggu visualisasi menuju Candi Borobudur, Candi Mendut, dan Candi Pawon dan perlu segera dilaksanakan penataan dan penertiban. Berikut ini contoh visualisasi di sepanjang Koridor Palbapang yang dapat mengganggu arah pandang ke Candi Borobudur

4. Melakukan evaluasi bangunan yang berdiri dari tahun 2008 - 2015 dan melakukan penindakan secara tegas

Yang menjadi permasalahan tak terpecahkan adalah sampai saat ini memang masih belum ada penegasan terkait bangunan-bangunan yang didirikan tanpa IMB serta tidak selaras dengan pengaturan Perpres Kawasan Borobudur baik dari aparatur pemerintah maupun penegakan aturannya. Sampai saat ini pun, masih dilakukan tahap revisi perda mengenai rencana tata ruang wilayah Kabupaten Magelang agar dapat selaras

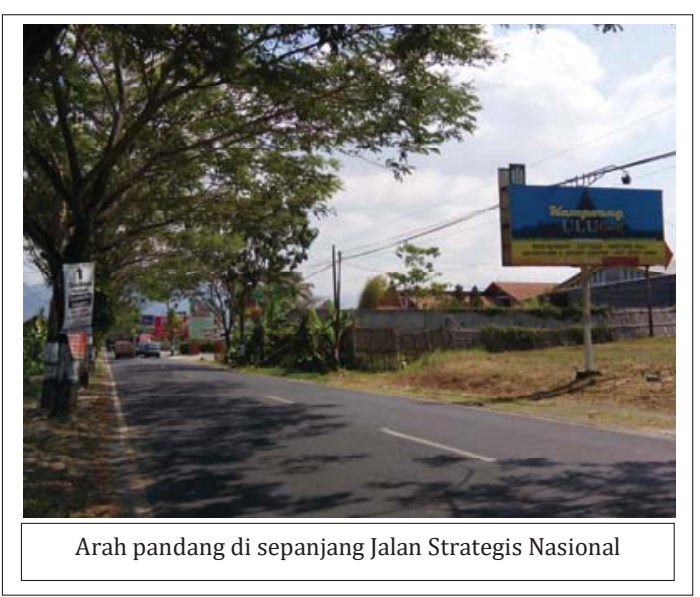

Sumber : Dokumen pribadi 2015 dan sejalan dengan Perpres Kawasan Borobudur karena dalam Pasal 46 Perpres Kawasan Borobudur telah dengan tegas mneyatakan mengenai pemanfaatan ruang di kawasan yang tidak selaras dengan Perpres Kawasan Borobudur.

5. Setiap pemanfaatan yang akan dilaksanakan di Kawasan Borobudur terutama SP I didahului dengan penggalian arkeologi (ekskavasi)

Keputusan Menteri Pendidikan dan Kebudayaan Republik Indonesia Nomor 286/M/2014 tentang Satuan Ruang Geografis Borobudur sebagai Kawasan Cagar Budaya Peringkat Nasional menetapkan Candi Borobudur, Candi Mendut, Candi Pawon, dan situs maupun lokasi yang berpotensi Cagar Budaya di Kawasan Borobudursebagai CagarBudaya Tingkat Nasional. Kaitannya dengan pemanfaatan ruang alangkah lebih baik sebelumnya dilaksanakan kegiatan penggalian arkeologi (ekskavasi) mengingat bahwa Kawasan Borobudur juga merupakan Kawasan Cagar Budaya.Oleh sebab itu setiap bentuk pemanfaatan yang ada disertai dengan studi yang dalam hal ini adalah untuk mengetahui apakah terdapat potensi cagar budaya di area atau lahan yang akan dibangun. Kondisi yang dapat dijumpai adalah terdapat beberapa bangunan mangkrak yang berada di area Koridor Palbapang yang pada dasarnya bisa dimanfaatkan.

Terkait dengan Peraturan Daerah Kabupaten Magelang Nomor 5 Tahun 2011 tentang Rencana Tata Ruang Wilayah Kabupaten Magelang Tahun 2010 2030 sedang dalam tahap perubahan isi dan kontent menyesuaikan dengan Perpres Kawasan Borobudur karena hal tersebut terkait dengan peta pemanfaatan

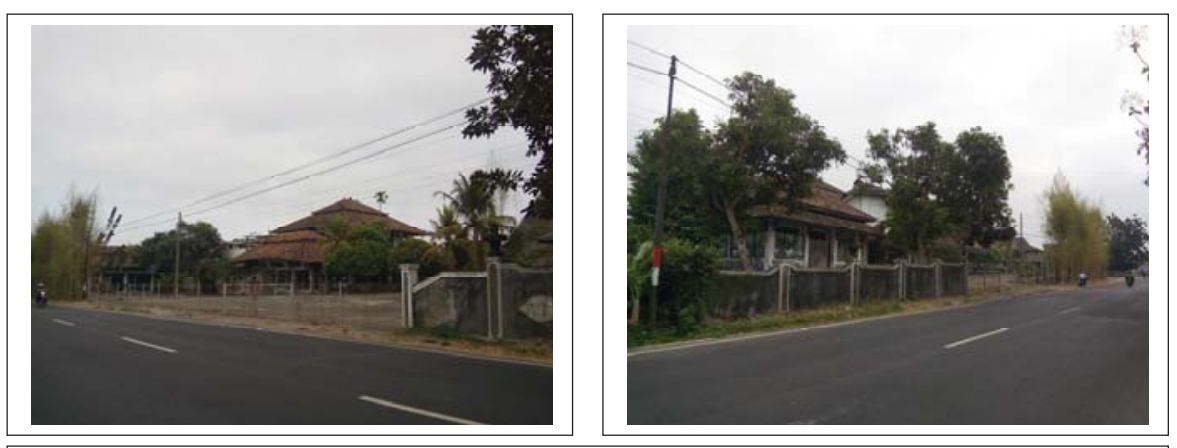

Salah satu bangunan yang sudah lama tidak digunakan sebenarnya bisa dimanfaatkan untuk kepentingan wisata kawasan (pasar seni) bekerjasama dengan masyarakat

Sumber : Dokumen pribadi 2015 
ruang di Kawasan Borobudur. pada salah satu pasal yaitu Pasal 24 Perda RTRW Kabupaten Magelang dinyatakan bahwa strategi pelestarian dan pemantapan fungsi lindung pada kawasan cagar budaya dilaksanakan dengan melindungi pemanfaatan ruang di sekitar bangunan bernilai sejarah atau situs purbakala serta meningkatkan nilai dan fungsi kawasan sebagai tempat wisata, kegiatan pecinta alam, obyek penelitian dan pendidikan yang pelaksanaan dan pengelolaannya dilaksanakan secara terpadu. Pasal tersebut bisa dikatakan memiliki cakupan yang kurang spesifik dan masih memungkinkan adanya celah. Pada Pasal 8 Perpres Kawasan Borobudur dengan jelas telah memberikan pembatasan mengenai strategi pelindungan karakter kawasan diantaranya adalah mempertahankan Kawasan Cagar Budaya dari kerusakan permanen, mencegah alih fungsi lahan kawasan pertanian dan kawasan hutan, membatasi perkembangan kawasan terbangun perkotaan, dan membatasi kegiatan pemanfaatan yang dapat mengancam kerusakan situs maupun potensi yang belum tergali.

Potensi - potensi yang belum tergali di Kawasan Borobudur mendapat perhatian karena pada dasarnya Kawasan Borobudur adalah merupakan taman arkeologi yang masih menyimpan potensi cagar budaya misalnya di Desa Ngrajek dimana banyak pula ditemukan batubatu berrelief dengan motif yang berbeda dengan batu komponen Candi Borobudur, Candi Mendut, maupun Candi Pawon yang memungkinkan dilakukan kajian lebih lanjut mengenai potensinya.

\section{PENUTUP}

\section{a. Simpulan}

1. Permasalahan yang ada terkait dengan implementasi Peraturan Presiden Nomor 58 Tahun 2014 tentang Rencana Tata Ruang Kawasan Borobudur dan Sekitarnya:

- Masyarakat merasa hak kepemilikan lahan miliknya dibatasi dengan terbitnya Perpres Kawasan Borobudur karena kurang pahamnya masyarakat terhadap pengaturan pemanfaatan ruang di kawasan

- Belum maksimalnya sosialisasi kepada masyarakat terkait dengan penetapan KSN

- Belum sinerginya program kerja antar instansi terkait karena belum intensnya koordinasi dan sinergi instansi terkait dalam rangka pengelolaan Kawasan Borobudur

- Pihak investor yang "menabung”lahan di Kawasan Borobudur yang menjadi daya tarik masyarakat untuk menjual lahan yang dimilikinya

2. Penanganan permasalahan yang dihadapi dalam pelestarian Kawasan Borobudur tersebut diantaranya adalah :

- Mereview Peraturan Daerah Kabupaten Magelang Nomor 5 Tahun 2011 tentang Rencana Tata Ruang Wilayah Kabupaten Magelang Tahun $2010-2030$

- Melakukan sosialisasi Peraturan Presiden Nomor 58 Tahun 2014 tentang Rencana Tata Ruang Kawasan Borobudur dan Sekitarnya

- Melakukan penataan dan penertiban terhadap sarana informasi di sepanjang area Koridor Palbapang

- Melakukan evaluasi bangunan yang berdiri dari tahun 2008 - 2015 dan melakukan penindakan secara tegas

- Setiap pemanfaatan yang akan dilaksanakan di Kawasan Borobudur terutama SP I didahului dengan penggalian arkeologi (ekskavasi)

- Melaksanakan koordinasi antar instansi terkait dalam pengelolaan Kawasan Borobudur yang terintegrasi dan bersinergi

Pengaturan dan aturan yang tercantum dalam Perpres Kawasan Borobudur dimaksudkan untuk mewujudkan Kawasan Borobudur sebagai Kawasan Strategis Nasional yang lestari sejalan dengan statusnya sebagai Kawasan Cagar Budaya Peringkat Nasional dan Warisan Budaya Dunia.

\section{b. Saran}

- Melakukan pendataan bangunan baru di Kawasan Borobudur dan mengkaji keselarasan bangunan tersebut dengan pemanfaatan ruang Kawasan Borobudur, sehingga bisa segeraditindaklanjuti dengan penegakan Pasal 46 Perpres Kawasan Borobudur

- $\quad$ Sosialisasi yang dilaksanakan kepada masyarakat di Kawasan Borobudur tidak hanya mengenai cagar budaya tetapi juga sosialisasi Perpres Kawasan Borobudur agar dapat meningkatkan peran serta masyarakat dalam melindungi Kawasan Borobudur. 
Sosialisasi dilaksanakan dengan mendatangi masyarakat secara langsung di desa maupun masingmasing dusun terutama di desa yang termasuk dalam SP I Kawasan Borobudur dan setiap pemanfaatan yang akan dilaksanakan di Kawasan Borobudur terutama SP I didahului dengan penggalian arkeologi (ekskavasi)

- Segera melaksanakan rapat koordinasi antar lintas sektoral yang berkepentingan terhadap dan di Kawasan Borobudur agar tercapai visi misi yang terintegrasi dalam program kerja masing-masing instansi demi mewujudkan Kawasan Borobudur sebagai Kawasan Cagar Budaya dan Warisan Dunia yang berkelanjutan dan bermasyarakat.

\section{DAFTAR PUSTAKA}

Tim Monitoring dan Evaluasi Kawasan. 2015. Laporan Monitoring dan Evaluasi Kawasan. Borobudur : Balai Konservasi Borobudur

Suhartono, Yudi. 2008. Pelestarian Sumber Daya Arkeologi dalam Konteks Keruangan di Kawasan Borobudur (Studi Kasus Borobudur, Mendut, dan Pawon). Tesis. Yogyakarta : Universitas Gajah Mada

Undang-undang Republik Indonesia Nomor 26 tahun 2007 tentang Penataan Ruang

Undang-undang Republik Indonesia Nomor 11 tahun 2010 tentang Cagar Budaya
- Peran serta pemerintah daerah dalam melakukan review Peraturan Daerah Kabupaten Magelang Nomor 5 Tahun 2011 tentang Rencana Tata Ruang Wilayah Kabupaten Magelang Tahun 2010 - 2030, melakukan penataan dan penertiban terhadap sarana informasi di sepanjang area Koridor Palbapang, dan melakukan evaluasi bangunan yang berdiri dari tahun 2008 - 2015 serta menindaklanjutinya.

Peraturan Pemerintah Nomor 26 tahun 2008 tentang Rencana Tata Ruang Wilayah Nasional

Peraturan Presiden Nomor 58 Tahun 2014 tentang Rencana Tata Ruang dan Wilayah Kawasan Strategis Nasional Borobudur dan Sekitarnya

Keputusan Menteri Pendidikan dan Kebudayaan Republik Indonesia Nomor 286/M/2014 tentang Satuan Ruang Geografis Borobudur sebagai Kawasan Cagar Budaya Peringkat Nasional

Peraturan Daerah Kabupaten Magelang Nomor 5 Tahun 2011 tentang Rencana Tata Ruang Wilayah Kabupaten Magelang Tahun 2010 - 2030 